\title{
ИЗМЕНЧИВОСТЬ МИКРОБИОТЫ ПРИ РАЗЛИЧНЫХ РЕЖИМАХ УВЛАЖНЕНИЯ ПОЧВ
}

\author{
(C) 2018 г. Ф.Н.Лисецкий*, @ , А. В. Землякова*, А. Д. Кириченко** \\ * Белгородский государственный национальный исследовательский университет, Россия, 308015 Белгород, ул. Победы, 85 \\ **Национальный научный центр “Институт почвоведения и агрохимии им. А.Н. Соколовского”, \\ Украина, 61024 Харьков, ул. Чайковская, 4 \\ ${ }^{\circledR}$ E-mail: liset@bsu.edu.ru \\ Поступила в редакцию 01.02.2017 г.
}

\begin{abstract}
С использованием данных о численности таксономических, физиологических и эколого-трофических групп микроорганизмов выполнен анализ сезонных изменений их структуры в условиях искусственного (орошение) и природного (мочарообразование) режимов увлажнения почв. Со статистической достоверностью установлено, что наибольший отклик на изменения, вызываемые разными режимами увлажнения почв, наблюдается в численности аэробных целлюлозоразрушающих микроорганизмов, денитрификаторов и грибов. Отмечено, что противоэрозионная устойчивость степных почв при орошении объясняется совместным действием физико-химических и биологических процессов и, в частности, большей численностью водорослей, грибов, аэробных целлюлозоразрушающих микроорганизмов и олигонитрофилов.
\end{abstract}

DOI: $10.1134 / \mathrm{S} 0002332918040094$

Микроорганизмы и микробиологические процессы играют важную роль в формировании плодородия почв и питании растений (Orudzheva, 2011; Kuzyakov, Blagodatskaya, 2015). Почвы, будучи биокосной системой и компонентом биогеоценоза, являются средой для жизнедеятельности микроорганизмов, играющих ведущую роль в процессах почвообразования и в значительной степени определяющих основное свойство почв плодородие.

Многими авторами (Blagodatskii et al., 2008; Sorokin, 2009; Dobrovol'skaya et al., 2015 и др.) показано, что биохимические процессы оказывают влияние практически на все параметры функционирования почв, и особенно их верхнего слоя. Микробные ценозы чрезвычайно изменчивы по численности и составу, что определяется динамикой основных экологических факторов.

Выявлено, что под воздействием оросительных мелиораций меняется интенсивность деятельности микрофлоры: увеличивается численность аммонификаторов, нитрификаторов и уменьшается число денитрификаторов, заметно возрастает численность азотобактера (Сухова и др., 1988; Rietz, Haynes, 2003; Guo et al., 2017 и др.). Кроме того, происходит увеличение продолжительности микробиологической активности.

При объяснении феномена повышения противоэрозионной устойчивости черноземных и темно-каштановых почв на юге Украины (Shvebs et al., 1988) отмечено положительное влияние орошения на микрофлору: увеличивается общая численность микроорганизмов, усиливается нитрификационная, аммонификационная способность, азотфиксация, дыхание, активность почвенных ферментов. Кроме того, установлено (Торжевський, Грабак, 1983), что состав микрофлоры, направленность микробиологических и биохимических процессов в значительной мере определяются интенсивностью орошения. Так, при увеличении поливов нормами от 500 до $1000 \mathrm{M}^{3} /$ га численность аэробных бактерий в южных черноземах снижается в 2 раза при активизации анаэробной микрофлоры (Сухова и др., 1988).

Важная составляющая и новизна нашего исследования - специальное изучение микробиоты в гидроморфных почвах, которые формируются при участии природных грунтовых вод. С 1960-х гг. в лесостепи и северной степи изменение климатических и гидрогеологических условий привело к возникновению спорадически переувлажненных участков агроландшафтов с гидроморфными почвами на склонах и даже на водоразделах. В результате переувлажнения происходит глубокая трансформация свойств, режимов и плодородия почв (Зайдельман и др., 1998). При этом преобладают негативные последствия (увеличение плотности сложения, глыбистости, разрушение минеральной части почвы, накопление солей и др.), 
Таблица 1. Характеристика объектов исследования

\begin{tabular}{|c|c|c|c|c|c|c|}
\hline Точка & $\begin{array}{l}\text { Место } \\
\text { отбора }\end{array}$ & Почва & $\begin{array}{c}\text { Тип } \\
\text { использования } \\
\text { земель }\end{array}$ & Агрофон & $\begin{array}{c}\text { Влажность } \\
\text { почвы, } \\
\%\end{array}$ & $\begin{array}{c}\text { Гумус, } \\
\%\end{array}$ \\
\hline 1 & $\mathrm{OO}$ & Чернозем южный тяжелосуглинистый & Неорошаемый & Подсолнечник & 18 & 3.1 \\
\hline 2 & $»$ & То же & Орошаемый & То же & 18.2 & 3.1 \\
\hline 3 & MK & $\begin{array}{l}\text { Чернозем карбонатный тяжелосугли- } \\
\text { нистый }\end{array}$ & Неорошаемый & Кукуруза & 20 & 2.1 \\
\hline 4 & $»$ & слабосмытый & Орошаемый & То же & 21.8 & 2.1 \\
\hline 5 & MK & $\begin{array}{l}\text { Чернозем карбонатный тяжелосугли- } \\
\text { нистый }\end{array}$ & Неорошаемый & $»$ & 18.3 & 2.9 \\
\hline 6 & » & То же & Орошаемый & Картофель & 21.7 & 2.9 \\
\hline 7 & ХБ & Темно-каштановая среднесуглинистая & Неорошаемый & Озимая пшеница & 20.9 & 2.2 \\
\hline 8 & » & То же & Орошаемый & То же & 18.6 & 2.2 \\
\hline 9 & $\mathrm{OK}$ & $\begin{array}{l}\text { Чернозем обыкновенный маломощ- } \\
\text { ный легкосуглинистый слабосмытый }\end{array}$ & Неорошаемый & Кукуруза & 23.8 & 3 \\
\hline 10 & ОБ & $\begin{array}{l}\text { Чернозем типичный мочаристый тяже- } \\
\text { лосуглинистый }\end{array}$ & Мочар & Озимая пшеница & 34 & 3.7 \\
\hline 11 & $»$ & То же & $»$ & То же & 29.1 & 5.2 \\
\hline 12 & » & 》 & » & » & 27.2 & 5.2 \\
\hline 13 & » & $\begin{array}{l}\text { Лугово-черноземная тяжелосуглини- } \\
\text { стая почва }\end{array}$ & » & $»$ & 35.7 & 4.8 \\
\hline 14 & $»$ & $\begin{array}{l}\text { Чернозем типичный лугово-болоти- } \\
\text { стый мочаристый }\end{array}$ & $»$ & Залежь (осока) & 43.7 & $\mathrm{H} /$ д \\
\hline 15 & » & $\begin{array}{l}\text { Лугово-черноземная тяжелосуглини- } \\
\text { стая почва }\end{array}$ & » & Пашня & 34.6 & 4.8 \\
\hline
\end{tabular}

Примечание. Места отбора почвенных образцов: ОБ - Одесская обл., Балтский р-н; ОК - Одесская обл., Краснознаменский р-н; ОО - Одесская обл., Овидиопольский р-н; ХБ - Херсонская обл., Белозерский р-н (Украина); МК - Каушанский р-н (Молдова); н/д - нет данных.

т.е. в целом наблюдается ухудшение агрономических качеств гидроморфных почв.

Цель исследования - сравнительная оценка сезонной динамики численности сообществ микроорганизмов при орошении почв и в условиях формирования гидроморфных почв вне ирригационных систем.

\section{МАТЕРИАЛЫ И МЕТОДЫ}

Объект изучения - микробные сообщества в почвах с различным типом увлажнения. Исследованием охвачены орошаемые почвы и их неорошаемые аналоги в трех мелиоративных системах в степной зоне (точки $1,2,5-8)$, эродированные почвы (точки $3,4,9)$ и гидроморфные почвы в лесостепной зоне (точки 10-15) (табл. 1).

Для определения влияния увлажнения, дополняющего климатическую норму осадков с помощью орошения земель, выбраны оросительные системы в различных почвенно-климатических условиях. Изучаемые почвы степной зоны - сменяющие с севера на юг черноземы обыкновенные, карбонатные, южные и темно-каштановые почвы - характеризуются усилением аридизации, что отражается в уменьшении годовых сумм осадков в этих четырех почвенных подзонах: от 470 и 416 до 386 и 383 мм соответственно. В южностепных и сухостепных подзонах длительное время проводят орошение земель, что существенно меняет гидротермический режим и биологическую активность почв.

Из-за того что в лесостепной зоне хорошо проявляется перераспределение влаги по топографическому градиенту, выбраны объекты по катене: в верхней (точки 11 и 12) и нижней (точка 10) частях склона.

Локальные различия гидроморфных почв отражала следующая схема отбора образцов: верхняя (по склону) периферия мочара на пашне 
(точка 13), его гидроцентр в залежном режиме землепользования (точка 14) и нижняя часть мочара, вовлеченная в пашню (точка 15).

Отбор почвенных образцов в 15 точках проводили из пахотного слоя (0-20 см) в сезонной динамике (весна-лето-осень). Каждый образец формировался как смешанный из пяти индивидуальных проб. Число водопрочных агрегатов определяли методом мокрого просеивания.

За последние десятилетия систематика микроорганизмов претерпела значительные изменения благодаря прогрессу в разработке методов химического анализа и молекулярной биологии (Korshunova et al., 2015). Поэтому для получения наиболее полной картины отзывчивости микробиоты на изменения увлажнения в различных по генезису почвах исследование проводили по широкому спектру микроорганизмов, что создает основу для дальнейшего изучения их диагностических групп. Основные микробиологические определения выполняли по стандартным методикам (Зенова, Кураков, 1988; Методы..., 1991; Лысак и др., 2003). Анализ состава таксономических (бактерии, грибы, актиномицеты), ряда физиологических (нитрификаторы, аммонификаторы, олигонитрофилы, денитрификаторы, целлюлозоразрушающие) и трофических (олиготрофы и эвтрофы) групп микроорганизмов проводили методом посева почвенной суспензии на плотные и жидкие питательные среды (Методы..., 1991): мясопептонный агар (МПА) для учета бактерий, усваивающих органические формы азота; крахмалоаммиачный агар (КАА) для бактерий, утилизирующих минеральные формы азота и актиномицетов; сахарозо-минеральная среда Ваксмана-Рихтера для грибов. Коэффициент олиготрофности определяли как отношение численностей микроорганизмов, выросших на голодном агаре и на МПА. Число олигонитрофилов учитывали на среде Эшби, нитрификаторов - на выщелоченном агаре с аммонийно-магниевой солью фосфорной кислоты $\left(\mathrm{NH}_{4} \mathrm{MgPO}_{4}\right)$, денитрификаторов - на среде Гильтая, аэробных и анаэробных целлюлозоразрушающих - на средах Имшенецкого и Гетчинсона соответственно. Численность почвенных водорослей (по 10-15 индивидуальным пробам) определяли методом люминесцентной микроскопии в свежих образцах почвы и методом Штины-Панкратовой после инкубации в оптимальных условиях (Штина, 1984; Бабьева, Зенова, 1989). Для характеристики обеспеченности почв минеральным азотом и степени выраженности процесса нитрификации определение нитратного азота проводили дисульфофеноловым методом, аммиачного - с реактивом Несслера. Для оценки нитрификационной и аммонификационной способностей почв использовали видоизмененный метод Ваксмана (Федоров, 1960).
Химический анализ проб проводили в лаборатории микробиологии почв Национального научного центра "Институт почвоведения и агрохимии” (Харьков, Украина). Статистическую обработку результатов выполняли с помощью программы Statistica. Для обработки экспериментальных данных использовали метод дисперсионного анализа. Классификационное сходство объектов определяли путем интерпретации результатов кластерного анализа (метод Уорда, Евклидова дистанция, значения нормированы по среднеквадратическому отклонению).

\section{РЕЗУЛЬТАТЫ И ОБСУЖДЕНИЕ}

Экологические особенности микробиологии почв могут быть установлены в пространственновременно́м аспекте рассмотрения численности таксономических, эколого-трофических и ряда физиологических групп микроорганизмов для отличающихся по генезису почв, для условий богары, орошения и природного гидроморфизма почв, а также по отдельным сезонам года.

Самый северный (из изученных) подтип черноземов - обыкновенный (табл. 2) - отличается от других неорошаемых черноземов (карбонатных и южных) более высокой численностью аммонификаторов, денитрификаторов, нитрификаторов, а также аммонификационной способностью, но близок или уступает по численности целлюлозоразрушающих микроорганизмов и характеризуется более низкой активностью процесса нитрификации. Черноземы карбонатные, которые в Молдове выделяют как самостоятельный подтип почв, в определенной степени аналогичны южным черноземам (Lisetskii et al., 2013). Coпоставление микробиологии всех почв Молдовы (Мехтиев, 1984) показало, что черноземы карбонатные (при среднем содержании $\mathrm{CaCO}_{3}$ в верхнем слое 2-2.5\%) отличаются от тех подтипов, которые расположены к северу, меньшим содержанием бактерий и грибов, но большей долей актиномицетов. В черноземах содержание нитратного азота было выше только в обыкновенном черноземе по сравнению с темно-каштановой почвой, но при орошении эти различия сглаживались.

При ирригации развитие бактериальной микрофлоры и грибов стимулируется повышенной влажностью в орошаемых почвах (Matei et al., 2011). Однако у генетически различных почв с определенными физико-химическими свойствами это проявляется по-разному.

Сопоставление почв по среднесезонной численности основных таксономических и трофических групп микроорганизмов показало, что темно-каштановые неорошаемые почвы только по числу грибов близки к южным черноземам, а по 
Таблица 2. Численность водорослей (осень), аммонифицирующих микроорганизмов, нитрификаторов, денитрификаторов и активность процессов аммонификации/нитрификации (среднее за сезон)

\begin{tabular}{|c|c|c|c|c|c|c|c|c|}
\hline \multirow[t]{2}{*}{ Точка } & \multirow[t]{2}{*}{$\begin{array}{c}\text { Водоросли } \\
\text { в слое } 0-2 \text { см, } \\
\text { тыс. } / \Gamma\end{array}$} & $\begin{array}{l}\text { Аммони- } \\
\text { фикаторы }\end{array}$ & $\begin{array}{c}\text { Денитри- } \\
\text { фикаторы }\end{array}$ & \begin{tabular}{|c} 
Аммони- \\
фика- \\
ционная \\
способность \\
$\mathrm{N}-\mathrm{NH}_{4}$
\end{tabular} & \begin{tabular}{|c|} 
Нитри- \\
фика- \\
ционная \\
способность \\
$\mathrm{N}-\mathrm{NO}_{3}$
\end{tabular} & $\begin{array}{l}\text { Подвиж- } \\
\text { ный азот }\end{array}$ & \multirow[t]{2}{*}{$\begin{array}{c}\text { Нитри- } \\
\text { фикаторы, } \\
\text { тыс./1 г }\end{array}$} & \multirow[t]{2}{*}{$\begin{array}{c}\text { Коэф- } \\
\text { фициент } \\
\text { олиго- } \\
\text { трофности }\end{array}$} \\
\hline & & \multicolumn{2}{|c|}{ млн./1 г почвы } & \multicolumn{3}{|c|}{ мг/100 г абсолютно сухой почвы } & & \\
\hline 1 & 2.4 & 3 & 9.3 & 0.7 & 2.6 & 0.5 & 2.1 & 2.2 \\
\hline 2 & 2.9 & 3.7 & 27.5 & 1.1 & 3 & 0.6 & 3.2 & 1.3 \\
\hline 3 & 2.3 & 3.5 & 5.8 & 0.7 & 2.7 & 0.6 & 1.9 & 1.8 \\
\hline 4 & 3.1 & 5.9 & 39.7 & 1 & 2.6 & 0.7 & 2.4 & 0.9 \\
\hline 5 & 29.3 & 3 & 6.7 & 1.1 & 2.9 & 0.4 & 1.6 & 2.2 \\
\hline 6 & 2.8 & 4.3 & 18.3 & 1.5 & 3 & 0.5 & 2.7 & 1.6 \\
\hline 7 & 33 & 7.3 & 24.9 & 1.5 & 3.7 & 0.7 & 2.9 & 1.5 \\
\hline 8 & 42.3 & 7.6 & 62.8 & 2.1 & 3.9 & 0.6 & 2.9 & 1.4 \\
\hline 9 & 22.1 & 4.5 & 8.9 & 1.2 & 2.2 & 0.6 & 2.9 & 1.6 \\
\hline 10 & 28.2 & 5.7 & 9.4 & 1 & 3.5 & 0.4 & 2.1 & 0.9 \\
\hline 11 & 8.3 & 6.9 & 32.2 & 1 & 3.4 & 0.7 & 3.4 & 0.9 \\
\hline 12 & 21.3 & 6.8 & 12.1 & 0.7 & 3.1 & 0.8 & 3.5 & 1.3 \\
\hline 13 & 20.7 & 7.4 & 19.9 & 1.1 & 3.4 & 0.5 & 2.8 & 2.2 \\
\hline 14 & 35 & 12.7 & 107.6 & 0.8 & 1.7 & 0.9 & 1.2 & 2.8 \\
\hline 15 & 41.4 & 13.7 & 63.4 & 1.5 & 1.8 & 0.8 & 1.9 & 2.6 \\
\hline
\end{tabular}

иным группам микроорганизмов значительно отличаются от других почв. Особенно существенны отличия темно-каштановых неорошаемых почв по численности водорослей, аммонификаторов и денитрификаторов. У темно-каштановых почв наблюдалась более высокая нитрификационная способность, чем у черноземов (на $31 \%$ в условиях богары и на 27\% при орошении). Это можно объяснить более узким диапазоном отношения содержания углерода гуминовых и фульвокислот $\left(\mathrm{C}_{\Gamma \mathrm{K}}: \mathrm{C}_{\Phi \mathrm{K}}\right)$, что характеризует большую доступность органического вещества для микроорганизмов. Так, на 1 г гумуса в темно-каштановых почвах по сравнению с черноземными приходится вдвое больше микробных клеток (Кириченко, 1988).

Результаты дисперсионного анализа данных по микробиологии почв показали, что существенными факторами влияния на микрофлору почв можно признать как регулирование влажности почв оросительными мелиорациями, так и сезонную динамику (сроки наблюдения). За исключением олиготрофов и актиномицетов, остальные группы микроорганизмов положительно реагируют на орошение. Отмечено (Зенова, Кураков, 1988; Методы..., 1991), что у актиномицетов наблюдается слабая отзывчивость на повышение влажности почвы, а их активность наблюдается при формировании условий для использования сравнительно трудно доступных для разложения субстратов.

Последовательный отбор наиболее разнящихся групп микроорганизмов в почвах при орошении и на богаре позволил выделить первые четыре группы микроорганизмов в табл. 3, выборочные средние которых по результатам дисперсионного анализа различают почвы на 5\%-ном уровне значимости. Их вклад как учтенного при анализе фактора составил 71\%. Однако по наименьшей существенной разности $\left(\mathrm{HCP}_{05}\right)$ только анаэробные целлюлозоразрушающие микроорганизмы, денитрификаторы и грибы достоверно имеют более высокую численность на протяжении года в орошаемых почвах по сравнению с неорошаемыми аналогами.

Наиболее корректно роль орошения может быть оценена при сопоставлении объектов-аналогов (точки 2 и 1, 4 и 3, 6 и 5, 8 и 7). С использованием данных парных отношений численности микроорганизмов по трем сезонам установлено наибольшее превышение численности при оросительных мелиорациях у денитрификаторов (табл. 3). В среднем по сезонам коэффициент превышения численности денитрификаторов в орошаемых почвах по сравнению с их неорошаемыми аналогами $(n=12)$ составляет $4 \pm 0.9(p=0.95)$. В 
Таблица 3. Микробиологические показатели неорошаемых и орошаемых почв степной зоны и значения коэффициента превышения численности микроорганизмов в орошаемых условиях по отношению к неорошаемым аналогам $\left(K_{\text {op }}\right)$

\begin{tabular}{l|c|c|c|c|c}
\hline \multirow{2}{*}{\multicolumn{1}{c|}{ Группа микроорганизмов }} & \multicolumn{2}{|c|}{ Почва } & \multicolumn{3}{c}{$K_{\text {ор }}$} \\
\cline { 2 - 6 } & неорошаемая & орошаемая & весна & лето & осень \\
\hline Целлюлозоразрушающие анаэробные* & 21.7 & $52.2^{* * * *}$ & 2.13 & 4.45 & 4.54 \\
Денитрификаторы* & 11.7 & $37.1^{* * *}$ & 4.65 & 4.57 & 2.78 \\
Грибы** & 34.5 & $57.5^{* * *}$ & 2.14 & 1.7 & 1.36 \\
Бактерии, усваивающие минеральный азот* & 16.7 & 19.6 & 1.43 & 1.39 & 2.47 \\
Целлюлозоразрушающие аэробные** & 41.4 & 57.9 & 1.41 & 1.71 & 1.55 \\
Бактерии, усваивающие органический азот* & 4.5 & 5 & 1.32 & 1.24 & 1.2 \\
Нитрификаторы** & 2.1 & 2.8 & 1.41 & 1.3 & 1.65 \\
Актиномицеты* & 4.4 & 4.8 & 1.24 & 1.4 & 1.09 \\
Олигонитрофилы* & 40.6 & 51.8 & 1.48 & 1.3 & 1.22 \\
Олиготрофы* & 40.2 & 34 & 0.88 & 0.96 & 0.84 \\
Среднее & & & 1.85 & 2.08 & 1.89 \\
\hline
\end{tabular}

* млн./г; для табл. 3 и $4 .{ }^{* *}$ тыс./г; для табл. 3 и $4 .{ }^{* * *}$ Разность существенна по $\mathrm{HCP}_{05}$.

среднем с учетом сезонной изменчивости коэффициент превышения численности целлюлозоразрушающих анаэробов в орошаемых почвах по сравнению с их неорошаемыми аналогами составил $3.9 \pm 1.2(p=0.95)$. У остальных групп микроорганизмов (кроме олиготрофов) превышение численности за счет орошения было близким (табл. 3) - в среднем в $1.5 \pm 0.2$ раза $(p=0.95)$. Так, аэробные целлюлозоразрушающие микробы и олигонитрофилы положительно откликаются на орошение, за счет которого их численность в среднем (с учетом сезонности) в $1.56 \pm 0.36$ и в $1.33 \pm 0.18$ раза $(p=0.95)$ выше, чем в неорошаемых почвах соответственно.

Под влиянием орошения изменяется число микроорганизмов, участвующих в трансформации соединений азота, а также содержание подвижных форм азота и потенциальная способность почв к процессам аммонификации и нитрификации. Во всех вариантах и практически во все сроки наблюдений численность аммонифицирующих бактерий была выше (на 24-44\%) у орошаемых почв, особенно осенью. Увеличением числа аммонификаторов обусловливается повышение способности к мобилизации почвенного азота за счет протеолиза и дезаминирования в среднем для орошаемых вариантов на 30-50\%, что является предпосылкой увеличения в орошаемой почве содержания азота в аммонийной форме.

Спорадический анаэробиозис при орошении усиливается от весны к осени, когда он максимально выражен, о чем свидетельствует повышенное число целлюлозоразрушающих анаэробов. Отмеченные особенности в развитии микрофлоры орошаемых почв сохраняются на всем протяжении вегетационного периода. Исключение составляет темно-каштановая почва, где летом влажность неорошаемой почвы была выше влажности орошаемой. Из-за выпадения обильных осадков орошение не проводилось, а местоположение неорошаемого участка способствовало большему накоплению влаги в почве. В орошаемой темно-каштановой почве весной и летом было отмечено превышение в 2-4 раза числа денитрификаторов и в 2 раза числа анаэробных целлюлозоразрушающих микроорганизмов.

Ранее при сопоставлении черноземов различной степени карбонатности (Захаров, 1978) было показано, что общее содержание целлюлозной микрофлоры в черноземе без карбонатов было выше, чем в карбонатном. Это подтверждают и наши данные. К примеру, осенью численность целлюлозоразрушающих аэробных и анаэробных микроорганизмов была выше в черноземе обыкновенном по сравнению с карбонатным в 2.2 и 1.4 раза соответственно. В условиях орошения такое превышение сохраняется только для анаэробных микроорганизмов. В среднем по трем сезонам численность грибов при орошении карбонатных черноземов в 1.6-1.9 раза больше, чем на богаре. Во все сезоны, но особенно летом, когда влияние оросительных мелиораций усиливается, численность целлюлозоразрушающих аэробных и анаэробных микроорганизмов при орошении карбонатных черноземов была выше таковой на их неорошаемымх аналогах более чем в 2 раза.

Несмотря на то что к моменту отбора образцов весной орошение во всех мелиоративных системах еще не проводилось и влажность почв на орошаемых и неорошаемых участках была сходной, 
различия в составе микрофлоры отражают те устойчивые изменения, которые сохраняются в почве под влиянием предшествующего орошения. Данные, зафиксированные весной до начала поливов, показали, что орошение влияет на таксономическую структуру микробного ценоза и трофический режим почв пролонгировано. Так, были отмечены рост численности эвтрофной микрофлоры и значительное снижение олиготрофности ценоза, что свидетельствует о лучшем трофическом режиме в орошаемых почвах. Значения общей численности эвтрофов на протяжении вегетационного периода в орошаемых почвах превышают наблюдаемые значения в почвах неорошаемых аналогов в $1.4 \pm 0.31$ раза $(p=0.95)$. Если принять коэффициент олиготрофности в неорошаемых почвах за $100 \%$, то его значение в относительном выражении составит для орошаемых почв с учетом внутригодовой динамики $70 \pm 20 \%$ $(p=0.95)$.

Внутригодовая изменчивость численности микроорганизмов, которая может быть выражена посредством коэффициента вариации $(V, \%)$, позволяет определить их группы, наиболее чутко реагирующие на смену гидротермических условий. По внутригодовой изменчивости можно выделить три группы микроорганизмов: бактерии, усваивающие органический азот, олигонитрофилы, целлюлозоразрушающие аэробные с незначительной вариацией $(V<10 \%)$; актиномицеты, нитрификаторы со средней вариацией ( $V=10-$ $20 \%)$; грибы, денитрификаторы, олиготрофы, бактерии, усваивающие минеральный азот, целлюлозоразрушающие анаэробные микроорганизмы со значительной вариацией $(V>20 \%)$.

Наиболее динамичные изменения численности микроорганизмов (по десяти основным группам) наблюдались летом $(V=65 \%)$, несколько меньшие значения $V$ отмечалась весной (57\%) и осенью $(56 \%)$, т.е. во все сезоны изменчивость была значительной.

По результатам дисперсионного анализа сезонные различия численностей микроорганизмов достоверно $\left(F_{\phi}>F_{05}\right)$ обоснованы для четырех групп микроорганизмов (табл. 3), которые можно определить как наиболее чувствительные к изменениям условий увлажнения почв (анаэробные целлюлозоразрушающие микроорганизмы, денитрификаторы, бактерии, усваивающие минеральный азот и грибы).

Однонаправленные изменения от сезона к сезону были определены для пяти групп микроорганизмов (табл. 3). При этом от весны к лету и осени у денитрификаторов, грибов, олигонитрофилов и бактерий, усваивающих органический азот, численность снижалась и лишь число анаэробов становилось больше. Кроме того, число аммонификаторов от весны к лету и осени законо- мерно увеличивались: от $3.2 \pm 0.83$ и $4.53 \pm 1.54$ до $6.62 \pm 3.15$ млн./ 1 г почвы $(p=0.95)$ соответственно.

В отличие от неорошаемых почв, где в структуре преобладает фракция 0.5-0.25 мм, для орошаемых аналогов характерен существенный сдвиг к более крупным фракциям водопрочных агрегатов (2-1, 1-0.5 и несколько меньше в отношении фракции 3-2 мм). Можно предположить, что выявляемое при орошении степных почв повышение водопрочности агрегатов и противоэрозионной устойчивости (Shvebs et al., 1988; Bulygin, Lisetskiy, 1992) обусловлено не только увеличением микроагрегированности почв, но и более интенсивной микробиологической деятельностью.

Как было показано ранее при изучении микробных сообществ южного чернозема (Сухова и др., 1988), последействие орошения слабо проявляется в изменении состава бактериальных сообществ, в частности популяций актиномицетов, а водоросли, напротив, достаточно чувствительно реагируют на изменения, которые обусловлены орошением. Полученные нами данные об альгосинузиях в исследованных почвах (табл. 2) показывают, что наиболее благоприятные условия для развития альгофлоры складывались осенью, чему способствовало хорошее увлажнение почвы (21-24\%), поступление в почвы агроценозов свежего растительного вещества. При этом влияние орошения осенью нивелировалось. При сравнении орошаемых почв и их аналогов на богаре наибольшее число водорослей было отмечено на темно-каштановой почве в посеве озимой пшеницы (33-42 тыс./г). В орошаемых почвах микробные сообщества могут способствовать связыванию почвы и ее структурной устойчивости в слое $0-5 \mathrm{~cm}$ (Caesar-Tonthat et al., 2014). Поэтому определяли численность почвенных водорослей в слое 0-2 см. Противоэрозионный эффект почвенных водорослей проявлялся в том, что слизистые вещества склеивали почвенные частицы, а переплетающиеся нити водорослей механически скрепляли их. Как было показано в опытах (Marathe, 1972), почвенные водоросли увеличивали агрегацию почвенных частиц на 36-78\% в зависимости от типа почвы. С формированием почвенной структуры и повышением устойчивости почв связана также жизнедеятельность грибов, олигонитрофилов и целлюлозоразрушающих бактерий. В орошаемых почвах возрастает содержание олигонитрофилов, которые осуществляют процессы азотфиксации, а также характеризуются повышенной способностью к слизеобразованию и наряду с грибами (Сушкина, Цюрупа, 1973) принимают участие в структурообразовании почвы. Так как представители этих групп микроорганизмов положительно реагируют на орошение, то именно их влиянием можно объяснить ранее установленное (Shvebs et al., 1988) повышение противоэрозионной устойчивости почв в результате орошения. 
Таблица 4. Различия микробиологических показателей на смытых и мочаристых почвах в лесостепной зоне

\begin{tabular}{|c|c|c|c|c|c|c|c|}
\hline \multirow{2}{*}{ Группа микроорганизмов } & \multicolumn{3}{|c|}{ Катена } & \multicolumn{3}{|c|}{ Мочар } & \multirow{2}{*}{$\begin{array}{c}\text { Разница } \\
\text { между } \\
\text { точками } \\
14 \text { и } 13\end{array}$} \\
\hline & 10 & 11 & 12 & 13 & 14 & 15 & \\
\hline Денитрификаторы* & 9.4 & 32.2 & 12.1 & 19.9 & 107.6 & 47.6 & $87.7 * * *$ \\
\hline $\begin{array}{l}\text { Целлюлозоразрушающие анаэ- } \\
\text { робные* }\end{array}$ & 79.8 & 41.5 & 42.8 & 57.9 & 92.6 & 67.8 & $34.7 * * * *$ \\
\hline Олиготрофы* & 28.8 & 53.5 & 43.4 & 53.3 & 67.4 & 80.6 & 14.1 \\
\hline Олигонитрофилы* & 39.5 & 87 & 84.3 & 67.5 & 77.1 & 194 & 9.6 \\
\hline $\begin{array}{l}\text { Бактерии, усваивающие органи- } \\
\text { ческий азот* }\end{array}$ & 5.7 & 6.9 & 6.8 & 7.4 & 12.6 & 16.1 & 5.2 \\
\hline Актиномицеты* & 6.3 & 4.8 & 7.7 & 4.5 & 5.8 & 3.6 & 1.3 \\
\hline $\begin{array}{l}\text { Бактерии, усваивающие мине- } \\
\text { ральный азот* }\end{array}$ & 20.6 & 26.4 & 17.1 & 13.5 & 13.8 & 11.9 & 0.3 \\
\hline Нитрификаторы** & 2.16 & 3.44 & 3.46 & 2.85 & 1.2 & 1.9 & -1.7 \\
\hline Грибы** & 39.1 & 23.3 & 32.4 & 24.0 & 18.1 & 21.4 & -5.9 \\
\hline $\begin{array}{l}\text { Целлюлозоразрушающие аэроб- } \\
\text { ные* }\end{array}$ & 33.4 & 50.2 & 45.4 & 45.2 & 36.4 & 63.8 & -8.8 \\
\hline
\end{tabular}

***, **** Разность существенна на $1 \%$ - и 5\%-ном уровнях значимости соответственно.

Разложение целлюлозы микроорганизмами имеет связь с процессами гумусообразования и формирования водопрочной структуры почв. Этот процесс осуществляется комплексом специфических микроорганизмов (грибов и бактерий, включая актиномицетов), характеризующихся различной требовательностью к экологическим факторам. Так, аэробные целлюлозоразрушающие микроорганизмы положительно реагируют на орошение, при котором их численность в среднем была на $40 \%$ выше, чем на богаре. Следовательно, при орошении интенсифицируется трансформация растительного вещества, что, несомненно, влияет на процессы структурообразования и водоудерживающую способность почв.

Используя результаты кластерного анализа по данным табл. 4, можно выделить три классификационные группы микроорганизмов, диагностирующих основные комплексы микробиологических процессов при природном гидроморфизме почв: актиномицеты, нитрификаторы и бактерии, усваивающие органический азот; грибы и бактерии, усваивающие минеральный азот; остальные группы при опосредованном участии олигонитрофилов.

Путем сопоставления ширины 95\%-ного доверительного интервала средних значений численности по десяти группам микроорганизмов у всех гидроморфных почв (табл. 4) со значениями в гидроцентре мочара (точка 14) установлено, что при избыточном увлажнении почв на протяжении года достоверно меньшие значения наблюдаются по нитрификаторам и целлюлозоразрушаю- щим аэробным микроорганизмам, а более высокие значения - по денитрификаторам и анаэробным микроорганизмам.

Гидроморфные почвы характеризуются высокой численностью аммонификаторов, а минеральный азот представлен преимущественно аммонийной формой. В гидроцентре мочара (точка 14) самая высокая численность таких функциональных групп, как олигонитрофилы и денитрификаторы, была выявлена весной. Летом в гидроцентре мочара при высоких значениях влажности и температуры активизируются анаэробные процессы, число аэробов снижается, а высокие значения коэффициента олиготрофности выступают индикатором неблагоприятных условий для микробного ценоза, так как влажность почвы превышает оптимальную. У гидроморфных почв численность почвенных водорослей достигала максимума осенью (21-41 тыс./Г), а в гидроцентре мочара их развитие наблюдалось также и весной, и летом, но на очень низком уровне $(0.1-0.2$ тыс./г). Тем не менее в условиях оптимального увлажнения лесостепи между верхними (точки 11, 12) и нижней (точка 10) частями склона, отличающимися по степени эродированности почв, установлены различия значений численности для всех основных групп микроорганизмов (табл. 4). По результатам дисперсионного анализа, основанного на средних данных по сезонам, у гидроморфных почв (точки 10-15) позиция в рельефе не является значимым фактором для дифференциации численности микроорганизмов. По результатам кластерного анализа пяти гидроморф- 
ных почв по численности десяти групп микроорганизмов обоснован наиболее своеобразный (в классификационном отношении) объект, сравнение которого с гидроцентром мочара (точка 14) позволяет определить наиболее сильное влияние избыточного увлажнения почв на микрофлору. Такой самобытный объект - лугово-черноземная пахотная почва со среднещелочной реакцией почвенного раствора ( $\mathrm{pH} 8.2$ ), расположенная на периферии мочара (точка 13). Различия при сопоставлении точек 14 и 13 (табл. 4) в наибольшей степени (с учетом фактора сезонности) отражаются на численности денитрификаторов $(p=0.99)$ и целлюлозоразрушающих анаэробных микроорганизмов весной и летом $(p=0.95)$. Таким образом, более активное развитие этих двух групп микроорганизмов прежде всего сближает микробиологические особенности орошаемых и гидроморфных почв.

\section{ЗАКЛЮЧЕНИЕ}

Проведенный анализ широкого спектра данных о микробиологии почв с разным режимом увлажнения показал, что и режимы увлажнения, и внутригодовая динамика гидротермических условий - существенные факторы, влияющие на микрофлору почвы.

При анализе таксономических и функциональных особенностей микробного ценоза орошаемых почв выявлены существенные изменения, которые могут инерционно сохраняться в отсутствие полива, но при благоприятных погодных условиях.

Учет межсезонных различий в численности микроорганизмов позволил обосновать наиболее чувствительные группы микроорганизмов к изменениям условий увлажнения почв за счет мелиораций: анаэробные целлюлозоразрушающие микроорганизмы, денитрификаторы, грибы и бактерии, усваивающие минеральный азот.

В орошаемых почвах по сравнению с неорошаемыми аналогами на протяжении года (при высокой межсезонной вариабельности микробиологических показателей) более высокая численность достоверно установлена у анаэробных целлюлозоразрушающих микроорганизмов, денитрификаторов и грибов. Их численность в орошаемых почвах может служить тестовым показателем изменений гидротермического режима.

Мелиоративное регулирование влажности степных почв и природный гидроморфизм в условиях лесостепи отражаются на микробиоте почв во многом сходным образом: по шести микробиологическим показателям из десяти различия близки ( $<40 \%$ при использовании относительных единиц сравнения). Однако орошаемые почвы имеют более многочисленную микрофлору в составе нитрификаторов, грибов и анаэро- бов, чем гидроцентр мочара, который отличается лишь по одному показателю - большей численности денитрификаторов.

Более высокая противоэрозионная устойчивость орошаемых почв по сравнению с неорошаемыми аналогами объясняется совместным действием физико-химических и биологических процессов, в частности улучшением водопрочности структуры (за счет укрупнения от 0.5 мм и более среднего диаметра агрегатов), а также устойчивыми изменениями численности отдельных групп микроорганизмов, перечень которых можно представить в ранжированном убывающем ряду: водоросли > грибы > аэробные целлюлозоразрушающие микроорганизмы > олигонитрофилы. Дальнейшее изучение представителей этих групп микроорганизмов целесообразно для решения вопросов оценки противоэрозионной устойчивости почв при орошении склоновых земель и при риске возникновения ирригационной эрозии.

Исследование выполнено при финансовой поддержке проекта № 5.4711.2017/6.7 в рамках Госзадания НИУ “БелГУ” на 2017-2019 гг.

\section{СПИСОК ЛИТЕРАТУРЫ}

Бабьева И.П., Зенова Г.М. Биология почв. М.: Изд-во МГУ, 1989. $336 \mathrm{c.}$

Зайдельман Ф.Р., Тюльпанов В.И., Ангелов Е.Н., Давыдов А.И. Почвы мочарных ландшафтов - формирование, агроэкология и мелиорация. М.: Изд-во МГУ, 1998. $160 \mathrm{c.}$

Захаров И.С. Образование гумусовых веществ целлюлозоразрушающими микроорганизмами. Кишинев: Штиинца, 1978. 116 с.

Зенова Г.М., Кураков А.В. Методы определения структуры комплексов почвенных актиномицетов и грибов. М.: Изд-во МГУ, 1988. 54 с.

Кириченко А.Д. Микрофлора, микробиологические процессы и их эволюция при интенсивном сельскохозяйственном использовании почв // Почвы Украины и повышение их плодородия. Киев: Урожай, 1988. Т. 1. С. 82-94.

Лысак Л.В., Добровольская Т.Г., Скворцова И.Н. Методы оценки бактериального разнообразия почв и идентификации почвенных бактерий. М.: МАКСПресс, 2003. 121 с.

Методы почвенной микробиологии и биохимии / Под ред. Звягинцева Д.Г. М.: Изд-во МГУ, 1991. 304 с.

Мехтиев С.Я. Микрофлора и другие биологические показатели // Почвы Молдавии. Т. 1. Кишинев: Штиинца, 1984. С. 136-140.

Сухова С.Н., Зенова Г.М., Зборишук Н.Г., Звягинцев Д.Г. Микробные сообщества южного чернозема как индикатор последействия орошения // Почвоведение. 1988. № 11. С. 82-85.

Сушкина Н.Н., Цюрупа И.Г. Микрофлора и первичное почвообразование. М.: Изд-во МГУ, 1973. 157 с.

Федоров М.В. Микробиология. М.: Госсельхозиздат, 1960. $351 \mathrm{c}$. 
Штина Э.А. Методы изучения почвенных водорослей // Микроорганизмы как компонент биогеоценоза. М.: Наука, 1984. С. 58-74.

Торжевський В.I., Грабак Н.X. Вплив способів обробітку грунту на мікрофлору чорнозему південного // Агрохімія і грунтознавство. 1983. № 46. С. 6670 .

Blagodatskii S.A., Blagodatskaya E.V., Bogomolova I.N. Microbial biomass and growth kinetics of microorganisms in chernozem soils under different land use modes // Microbiology. 2008. V. 77. № 1. P. 99-106.

Bulygin S.Yu., Lisetskiy F.N. Soil microaggregation as an index of erosion resistance // Euras. Soil Sci. 1992. V. 24. № 3. P. 59-65.

Caesar-Tonthat T., Stevens W.B., Sainju U.M., Caesar A.J., West M., Gaskin J.F. Soil-aggregating bacterial community as affected by irrigation, tillage, and cropping system in the northern great plains // Soil Sci. 2014. V. 179. № 1. P. 11-20.

Dobrovol'skaya T.G., Zvyagintsev D.G., Chernov I.Y., Golovchenko A.V., Zenova G.M., Lysak L.V., Manucharova N.A., Marfenina O.E., Polyanskaya L.M., Stepanov A.L., Umarov M.M. The role of microorganisms in the ecological functions of soils // Euras. Soil Sci. 2015. V. 48. № 9. P. 959-967.

Guo W., Andersen M.N., Qi X.-B., Li P., Li Z.-Y., Fan X.-Y., $Z$ hou $Y$. Effects of reclaimed water irrigation and nitrogen fertilization on the chemical properties and microbial community of soil // J. Integr. Agricult. 2017. V. 16. № 3. P. 679-690.

Korshunova T.Y., Mukhamatdyarova S.R., Loginov O.N. Taxonomic classification of the oil destructing bacterium using mass spectrometry methods by the results of analysis of cellular proteins and study of cellular fatty acids // Biol. Bull. 2015. V. 42. № 3. P. 220-225.
Kuzyakov Y., Blagodatskaya E. Microbial hotspots and hot moments in soil: Concept \& review // Soil Biol. Biochem. 2015. V. 83. P. 184-199.

Lisetskii F.N., Goleusov P.V., Chepelev O.A. The development of chernozems on the Dniester-Prut interfluve in the Holocene // Euras. Soil Sci. 2013. V. 46. № 5. P. 491-504.

Marathe K.V. Role of some blue-green algae in soil aggregation. The taxonomy and biology of blue-green algae // Proc. Sympos. Taxon. Biol. Blue Green Algae. Madras: Madras Univ., 1972. P. 328-331.

Matei G.-M., Matei S., Seceleanu I., Mocanu V., Dumitru S., Cotet $V$. Influence of irrigation on microbial communities and soil organic matter evolution in the Chernozem in Marculesti // J. Environ. Protect. Ecol. 2011. V. 12. № 4. P. 2101-2109.

Orudzheva N.I. Microbiological characteristics of different types of irrigated soils in the subtropical zone of Azerbaijan // Euras. Soil Sci. 2011. V. 44. № 11. P. 12411249.

Polyanskaya L.M., Ivanov K.E., Guzev V.S., Zvyagintsev D.G. Estimation of abundance dynamics of gram-negative bacteria in soil // Microbiology. 2008. V. 77. № 6. P. 760764.

Rietz D.N., Haynes R.J. Effects of irrigation-induced salinity and sodicity on soil microbial activity // Soil Biol. Biochem. 2003. V. 35 № (6). P. 845-854.

Shvebs G.I., Svetlichnyy A.A., Chernyy S.G. Soil resistance to erosion in the southern Ukraine and change there in due to irrigation // Soviet Soil Sci. 1988. V. 20. № 4. P. 68-74.

Sorokin N.D. Microbiological monitoring of disturbed ground ecosystems of Siberia // Biol. Bull. 2009. V. 36. № 6. P. 619-623.

\title{
Variability Microbiota in Different Regimes of Soil Moisture
}

\author{
F. N. Lisetskiii ${ }^{1, ~ \#, ~ A . ~ V . ~ Z e m l y a k o v a 1, ~ a n d ~ A . ~ D . ~ K i r i c h e n k o ~}{ }^{2}$ \\ ${ }^{1}$ Belgorod National Research University, ul. Pobedy 85, Belgorod, 308015 Russia \\ ${ }^{2}$ National Scientific Center “Institute of Soil Science And Agrochemistry Research”, \\ ul. Chaykovskaya 4, Kharkiv, 61024 Ukraine \\ \#e-mail: liset@bsu.edu.ru
}

\begin{abstract}
Analysis of seasonal changes in the ratio of microorganisms in conditions of irrigation and natural modes of soil moistening was performed using data on the number of taxonomic, physiological and ecological-trophic groups. The greatest response to changes that were caused by a different regime of soil moistening was observed in the number of aerobic cellulose-destroying microorganisms, denitrifies and fungi. The increase in the erosion resistance of steppe soils during irrigation is explained by the combined action of physicochemical and biological processes, and in particular by the greater amount of algae, fungi, aerobic cellulose-destroying microorganisms and oligonitrophils.
\end{abstract}

